\title{
Analisis Pemahaman Generasi Muda Terhadap Pengenaan Pajak Penghasilan Pengusaha Online (E-Commerce)
}

\author{
Analysis of Young Generation's Understanding of the Imposition of Online Entrepreneur \\ Income Tax(E-Commerce)
}

\section{Citra Windy Lubis ${ }^{\mathrm{a}, 1}$, Diana Sinaga ${ }^{\mathrm{b}, 2}$}

Program Studi Akuntansi, Fakultas Ekonomi dan Bisnis, Universitas Potensi Utama

e-mail: citra.windylubis@gmail.com

\begin{abstract}
ABSTRAK
E-Commerce merupakan model bisnis yang mempertemukan penjual dan pembeli secara online atau tanpa pertemuan langsung. Transaksi-transaksi yang dilakukan didalam E-Commerce berpotensi dalam pengenaan pajak, salah satunya pengenaan pajak penghasilan atas transaksi-transaksi terseebut.Pajak penghasilan ini dikenakan kepada wajib pajak orang pribadi yang dalam hal ini para generasi muda yang berusia 21 -30 tahun yang memiliki usaha dibidang E-Commerce.penelitian ini bertujuan untuk mengetahui dan menganalisi tingkat pemahaman generasi muda pelaku E-Commerce tentang pengenaan pajak penghasilan atas usaha mereka. Dengan melakukan wawancara kepada generasi muda yang memiliki usaha dibidang E-Commerce didapatkan hasil bahwa masih rendahnya tingkatpemahaman pajak penghasilan atas pendapatan dari melakukan kegiatan bisnis E-Commerce sehingga tingkat kesadaran dalam melaporan pajak penghasilannya juga masih rendah. Sosialisasi peraturan perpajakan atas E-Commerece juga masih rendah yang mengakibatkan para pelaku E-Commerce tidak memahami peraturan perpajakan E-Commereceyang berpotensi menghilangkan pendapatan Negara atas pajak penghasilan tersebut.
\end{abstract}

Kata Kunci :E-Commerce dan Pajak Penghasilan

\begin{abstract}
E-Commerce is a business model that brings together sellers and buyers online or without face-to-face meetings. Transactions carried out in E-Commerce have the potential to be subject to taxation, one of which is the imposition of income tax on these transactions. This income tax is imposed on individual taxpayers, in this case the young generation aged 21-30 years who have businesses. in the field of E-Commerce. This study aims to determine and analyze the level of understanding of the younger generation of E-Commerce actors regarding the imposition of income tax on their business. By conducting interviews with the younger generation who have businesses in the field of E-Commerce, it is found that the level of understanding of income tax on income from conducting E-Commerce business activities is still low so that the level of awareness in reporting income taxes is also still low. The socialization of tax regulations on E-Commerce is also still low, which causes E-Commerce actors to not understand the E-Commerce tax regulations that have the potential to eliminate state revenues from the income tax.
\end{abstract}

Keywords :E-Commerce and Income Tax

Disubmit: 17 November 2021

Info Artikel :

Direview: 13 Desember $2021 \quad$ Diterima : 20 Januari 2022

Copyright (C) 2022 - Journal UPU. All rights reserved.

\section{PENDAHULUAN}

Pendapatan terbesar Negara berasal dari penerimaan pajak. Pajak merupakan penerimaan Negara yang bertujuan untuk menngkatkan kemakmuran dan kesejahteraan rakyat. Pemerintah member 
tanggung jawab kepada rakyat dalam pembayaran pajak bagi rakyat yang memenuhi syarat dalam pengenaan pajak. Seperti yang telah diatur pada Pasal 23 AUndang-Undang dasar 1945 yaitu " Pajak dan pungutan yang bersifat memaksa untuk keperluan Negara diatur dengan undang-undang". Terdapat berbagai jenis pengenaan pajak, salah satunya adalah pajak penghasilan. Pajak penghasilan merupakan pajak yang dipungut berdasarkan penghasilan yang didapat oleh wajib pajak.

Perkembangan bisnis di Era Revolusi Industry 4.0 banyak dipengaruh oleh teknologi digital sehingga menciptakan dunia bisnis yang lebih mudah dalam melaksanakan kegiatan bisnisnya. Perkembangan ini menciptakan suatu model bisnis yang bernama E-Commerce atau yang lebih dikenal dengan perdagangan secara online. E-commerce merupakan model bisnis yang mempertemukan penjual dengan pembeli secara online dengan transaksi elektronik. Menurut OECD/G20 (2015), ECommerce adalah penjualan barang atau jasa yang dilakukan melalui jaringan komputer. Dapat digunakan baik untuk mempermudah pemesanan barang atau jasa yang kemudian dikirimkan melalui jalur konvensional, atau untuk memesan dan mengirimkan barang dan jasa secara lengkap secara elektronik. E-Commerce telah membawa banyak keuntungan seperti pengurangan biaya menjalankan bisnis, penetrasi pelanggan dan pemasok baru, peningkatan kualitas produk atau layanan, penciptaan rute atau arah baru untuk distribusi produk (Pham et al., 2011). Biaya rendah dalam melakukan perdagangan elektronik memungkinkan perusahaan kecil untuk mengakses pasar di seluruh dunia. ECommerce mampu berperan menjadi lokomotif pertumbuhan ekonomi digital di Indonesia. Keberhasilan E-Commerce turut mempopulerkan berbagai layanan digital lain, sebut saja layanan teknologi finansial, logistik pintar, tata kelola bisnis digital, hingga berhasil memberdayakan bisnis tradisional seperti warung dengan pendekatan kemitraan.

Globalisasi mendorong mobilitas barang, jasa, tenaga kerja dan modal, dengan perusahaan mencari keuntungan dan kondisi yang menguntungkan di berbagai negara di dunia. Sikka (2008) menyatakan bahwa dengan globalisasi, negara-negara bersaing berusaha memenuhi tuntutan perusahaan untuk biaya yang lebih rendah dan kewajiban sosial, untuk menarik bisnis. Basis pajak penjualan untuk pemerintah negara menyusut karena meluasnya penggunaan layanan yang tidak dikenakan pajak penjualan dan berlanjutnya pengecualian yang diberikan oleh undang-undang. Erosi juga disebabkan oleh pertumbuhan penjualan jarak jauh termasuk yang dilakukan melalui E-Commerce (online), telepon, dan katalog. Kerugian pendapatan dari E-Commerce umumnya timbul karena E-Commerce memungkinkan peningkatan penjualan jarak jauh yang signifikan, sehingga menyebabkan pergeseran dari pemungutan pajak penjualan di tempat penjualan menjadi pemungutan pajak penggunaan untuk barang yang digunakan, dikonsumsi, atau disimpan di negara bagian. Tingkat kepatuhan jauh lebih tinggi untuk pajak penjualan daripada pajak penggunaan, dan juga kepatuhan pajak penggunaan diperkirakan akan turun lebih jauh sebagai akibat dari E-Commerce. Kerugian pendapatan umumnya merupakan hasil dari penghindaran pajak, karena pajak penggunaan terutang meskipun pajak penjualan tidak dapat dipungut.

Ekonomi berbasis informasi muncul dengan penyediaan layanan yang mewakili lebih dari setengah dari semua kegiatan ekonomi di negara-negara industri. E-commerce merupakan sumber pendapatan bisnis yang signifikan. E-Commerce merupakan masalah kompleks yang melintasi perbatasan kota, kabupaten dan negara, perbatasan nasional, dan jenis pajak. Pertumbuhan E-Commerce menimbulkan masalah kompleks yang terkait dengan perpajakan transaksi multi-yurisdiksi, sumber penjualan, pendapatan, layanan atau transaksi tidak berwujud. Seluruh dunia sedang mengalami transisi yang luar biasa dalam bisnis, sekarang ini internet digunakan sebagai alat untuk bisnis. Menurut data statistik, 52\% penduduk dunia adalah pengguna internet (Internet WS, 2018). Di seluruh dunia sedang mengalami perkembangan E-Commerce yang cukup pesat, salah satunya adalah Indonesia. Indonesia merupakan salah satu Negara dengan pertumbuhan E-commerce tercepat didunia. Hal ini dapat dilihat dari grafik data berikut : 


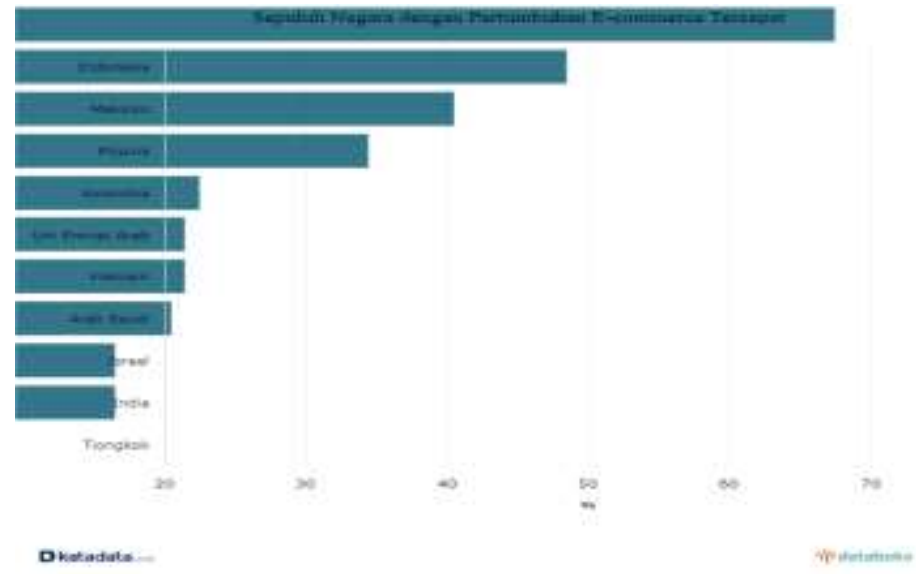

Gambar 1. Sepuluh Negara Dengan Pertumbuhan E-Commerce Tercepat Sumber : https://databoks.katadata.co.id

Dari grafik data diatas dapat dilihat perkembangan E-Commerce di Indonesia tercepat dibanding dengan Negara-negara lainnya. Tingginya laju pengguna E-Commerce di Indonesia tentunya disebabkan oleh beberapa factor yang mendasari perkembangan yang signifikan ini diantaranya adalah pertumbuhan penduduk yang meningkat, hingga perkembangan teknologi yang semakin maju. Dilihat dari pekembangannya jumlah transaksi-transaksi E-Commerce di Indonesia sangat meninggkat selama 5 tahun terakhir hal ini dapat dibuktikan dengan grafik data dibawah ini :

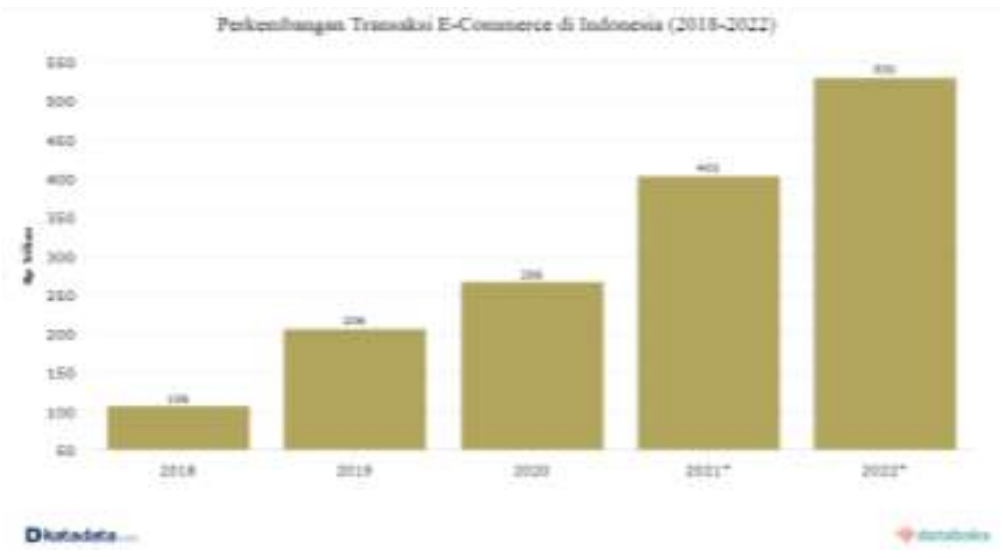

Gambar 2. Perkembangan Transaksi E-Commerece di Indonesia (2018-2022) Sumber : https://databoks.katadata.co.id

Pada grafik data diatas dapat dilihat perkembangan transaksi E-Commerce di Indonesia dari tahun 2018 - 2022 semakin meningkat. Tahun 2021 transaksi E-Commerce mencapai Rp 403 triliun yang meningkat sebesar 51,6\% dari tahun sebelumnya. Pada tahun 2022 diproyeksikan meningkat sebesar Rp 530 triliun yang artinya meningkat sebesar 31,4\% dari tahun sebelumnya. Generasi muda yang menuntut semua untuk instant. Sistem belanja online dihubungkan melalui jaringan internet, tanpa bertatap muka antar penjual-pembeli memudahkan pola hidup masyarakat yang ingin cepat, tetapi tidak menyita waktu mereka yang sibuk. Proses belanja pun menjadi mudah dan tidak rumit, terlebih memperoleh produk yang diinginkan juga tidak terbatas oleh negara. Produk dari berbagai macam negara bisa didapatkan dengan mudah, hanya melalui transaksi online. Selain memperluas target pasar, mereka juga tidak perlu selalu menghabiskan waktu untuk selalu bertatap muka dengan konsumen. Transaksi-transaksi online lebih banyak dilakukan oleh generasi muda yang dapat dilihat dari grafik data dibawah ini: 

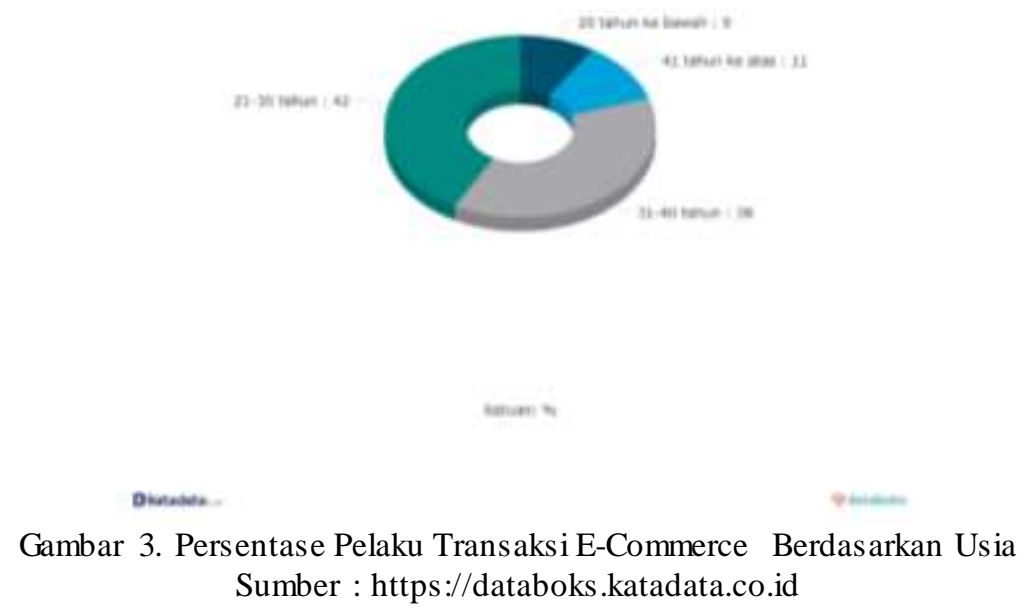

Grafik data diatas menunjukkan bahwa $42 \%$ penjual yang melakukan transaksi E-Commerce berusia diantara $21-30$ tahun., 38\% penjual diusia 31-40 tahun, $11 \%$ penjual berusia 41 tahun keatas, dan $9 \%$ penjual dalam transaksi E-Commerce ini dilakukan oleh 20 tahun kebawah. Di era sekarang ini banyak generasi muda mulai berfikir dalam pengembangan diri dan pengambangan perekonomiannya secara pribadi. Sehingga banyak generasi muda memanfaatkan model bisnis ECommerce sebagai suatu alternatif untuk meninggkan ekonominya berdasarkan kemudahaan dalam melakukan jual beli produk secara online dengan meminimalisir biaya oprasionalnya. Perdagangan online tidak memiliki batasan ruang dan waktu. Hal ini memberikan peluang untuk mendapatkan omset penjualan yang tidak terbatas.

Dengan semakin berkembangnya E-Commerce ini dapat disimpulkan bahwa para pengusaha perdagangan online sudah dapat ditetapkan secara maksimal dalam peenuhan kewajiban pajak untuk mendapatkan tambahan pendapatan Negara. Jika dilhat dari peraturan perundang-undangan perpajakan, E-Commerce berpotensi dalam pengenaan Pajak Pertambahan Nilai (PPN) untuk barang yang diperdagangkan dan Pajak Penghasilan $(\mathrm{PPh})$ terhadap penghasilan atau pendapatan yang diperoleh sebagai hasil dari perdangan tersebut.

Penerimaan pajak yang dipungut digunakan oleh pemerintah untuk mengembangkan perekonomian, pendidikan, masyarakat dan keamanan negara. Orang yang membayar pajak disebut pembayar pajak. Wajib pajak berasal dari berbagai pihak seperti orang pribadi, wali, perkumpulan, koperasi dan korporasi (Sumedi, 2010). Pesatnya pertumbuhan E-Commerce dewasa ini menimbulkan berbagai tantangan. Salah satu isu yang menonjol di kalangan pengusaha E-Commerce adalah mereka dapat menghindari perpajakan karena bisnis dilakukan secara online. Mereka berasumsi bahwa otoritas pajak tidak akan dapat mendeteksi pendapatan bisnis mereka. Ini karena bisnis E-Commerce yang dilakukan melalui Internet benar-benar berbeda dari bentuk bisnis lainnya (Coupey, 2001).

Li (2004) menyatakan bahwa tidak mengenakan pajak atau memberikan preferensi pajak kepada industri ini dapat sangat merugikan pemungutan pajak. Pajak lebih dari sekadar sumber pendapatan karena memainkan peran penting bagi pembangunan suatu negara. Sesuai dengan prinsip netralitas pajak, sistem perpajakan umumnya harus netral sehingga keputusan dibuat bukan untuk alasan pajak bisnis tetapi berdasarkan manfaat ekonominya.

Pengetahuan dalam memahami undang-undang perpajakan tentunya akan membantu wajib pajak untuk menghitung pajaknya (Jabbar dan Pope, 2008). Redae dan Sekhon (2016) menyatakan bahwa memahami pengetahuan dan perilaku kepatuhan wajib pajak merupakan tantangan bagi setiap pemerintah dan otoritas pajak terutama ketika menggunakan. Saad (2014) menunjukkan bahwa wajib pajak tampaknya memiliki pengetahuan yang kurang tentang aspek teknis sistem pajak penghasilan. Oleh karena itu, pengetahuan perpajakan sangat penting karena dapat mempengaruhi pemahaman 
wajib pajak dan secara tidak langsung dapat meningkatkan kepatuhan sukarela sehingga dapat menyebabkan penurunan penghindaran pajak. Untuk mencapai kepatuhan sukarela, pengetahuan pajak adalah penting. Hal ini karena kemampuan wajib pajak untuk memahami sistem perpajakan tergantung pada pengetahuannya tentang sistem dan hukum perpajakan. Misalnya, Self-Assessment System (SAS) meminta wajib pajak bertanggung jawab untuk menyatakan dan menghitung pajak mereka sendiri. Selain itu, wajib pajak juga memiliki pencatatan tambahan, perkiraan pajak lanjutan, dan pembayaran pajak bulanan di muka.

Penelitian ini bertujuan untuk menganalisi pemahaman generasi muda yang melakukan kegiatan bisnis dengan model bisnis E-Commerce terhadap pengenaan pajak penghasilan E-commerce. Dengan adanya tujuan dan latarbelakang diatas maka muncullah pertanyaan: Bagaimana pemahaman generasi muda terhadap pengenaan pajak penghasilan pengusaha online E-Commerce?

\section{TINJAUAN PUSTAKA}

\section{A. Pajak Penghasilan}

Pajak Penghasilan merupakan hal penting didalam perpajakan sebagai dasar penerimaan pendapatan Negara dan merupakan kewajiban bagi wajib pajak dalam melaporkan dan membayar pajak. Pengertian Pajak Penghasilan (PPh) Pasal 21 berdasarkanPeraturan Direktur Jenderal Pajak Nomor PER-32/PJ/2010 adalah pajak atas penghasilanberupa gaji, upah, honorarium, tunjangan dan pembayaran lain dengan nama dan dalambentuk apa pun sehubungan dengan pekerjaan atau jabatan, jasa, dan kegiatan yang dilakukanoleh orang pribadi subyek pajak dalam negeri. Subjek pajak penghasilan dikenai pajakapabila menerima atau memperoleh penghasilan. Subjek pajak yang menerima ataumemperoleh penghasilan dalam Undang-Undang No. 36 tahun 2008 tentang PajakPenghasilan $(\mathrm{PPh})$ disebut Wajib Pajak. Wajib Pajak dikenai pajak atas penghasilan yangditerima atau diperolehnya selama satu tahun pajak atau dapat pula dikenai pajak untukpenghasilan dalam bagian tahun pajak apabila kewajiban pajak subjektifnya dimulai atauberakhir dalam tahun pajak. Pajak Penghasilan merupakan jenis pajak subjektif yangkewajiban pajaknya melekat pada subjek pajak yang bersangkutan, artinya kewajiban pajaktersebut dimaksudkan untuk tidak dilimpahkan kepada subjek pajak lainnya.

\section{B. Pajak penghasilan final}

Pajak penghasilan final merupakan pajak penghasilan yangpengenaannya sudah final (berakhir) sehingga tidak dapat dikreditkan(dikurangkan) dari total Pajak Penghasilan yang terutang pada akhir tahunpajak. Berdasarkan Pasal 4 ayat (2) UU PPh, pajak penghasilan yangbesifat final terdiri atas:

a. Penghasilan berupa bunga deposito dan tabungan lainnya, bungaobligasi dan surat utang negara, dan bunga simpanan yang dibayarkanoleh koperasi kepada anggota koperasi orang pribadi.

b. Penghasila berupa hadiah undian.

c. Penghasilan dari transaksi saham dan sekuritas lainnya, transaksiderivatif yang diperdagangkan di bursa, dan transaksi penjualan sahamatau pegalihan penyertaan modal pada perusahaan pasangannya yangditerima oleh perusahaan modal ventura

d. Penghasilan dari transaksi pengalihan harta berupa tanah dan/ataubangunan, usaha jasa konstruksi, usaha real estat, dan persewaan tanahdan/atau bangunan, dan

e. Penghasilan tertentu lainnya (penghasilan dari pengungkapanketidakbenaran, penghentian penyidikan tindak pidana, dan lainlain). 


\section{Self Assessment System}

Self Assessment System adalah sistem penentuan pajak yang membebankan penentuan besaran pajak yang perlu dibayarkan oleh wajib pajak yang bersangkutan secara mandiri. Bisa dikatakan, wajib pajak adalah pihak yang berperan aktif dalam menghitung, membayar, dan melaporkan besaran pajaknya ke Kantor Pelayanan Pajak (KPP) atau melalui sistem administrasi online yang sudah dibuat oleh pemerintah. Peran pemerintah dalam sistem pemungutan pajak ini adalah sebagai pengawas dari para wajib pajak. Self assessment system biasanya diterapkan pada jenis pajak pusat. Misalnya adalah jenis pajak PPN dan PPh. Sistem pemungutan pajak yang satu ini mulai diberlakukan di Indonesia setelah masa reformasi pajak pada 1983 dan masih berlaku hingga saat ini. Sistem pemungutan pajak ini memiliki kekuarangan, yaitu karena wajib pajak memiliki wewenang menghitung sendiri besaran pajak terutang yang perlu dibayarkan, maka wajib pajak biasanya akan berusaha untuk menyetorkan pajak sekecil mungkin dengan membuat laporan palsu atas pelaporan kekayaan.

\section{Wajib Pajak Pada Pajak Penghasilan}

Pengertian wajib pajak didalam Pajak Penghasilan bisa disebut juga sebagai subjek pajak. Dalam Undang-Undang PPh, subjek pajak dibedakan antara subjek pajak dalam negeri dan subjek pajak luar negeri. Yang dimaksud dengan subjek pajak dalam negeri, yaitu:

a. Orang pribadi yang bertempat tinggal di Indonesia, orang pribadi yang berada di Indonesia lebih dari 183 (seratus delapan puluh tiga) hari dalam jangka waktu 12 (dua belas) bulan, atau orang pribadi yang dalam satu tahun pajak berada di Indonesia dan mempunyai niat untuk bertempat tinggal di Indonesia.

b. Badan yang didirikan atau bertempat kedudukan di Indonesia kecuali unit tertentu dari badan pemerintah yang memenuhi kriteria:

1. Pembentukannya berdasarkan ketentuan peraturan perundangundangan.

2. Pembiayaannya bersumber dari Anggaran Pendapatan dan Belanja Negara atau Anggaran Pendapatan Belanja Daerah.

3. Penerimaannya dimasukkan dalam anggaran Pemerintah Pusat atau Pemerintah Daerah; dan pembukuannya diperiksa oleh aparat pengawasan fungsional Negara.

4. Warisan yang belum terbagi sebagai satu kesatuan menggantikan yang berhak

\section{E. E-Commerce}

E-Commerce adalah proses hubungan dagang bisnis ke bisnis, untukmemudahkan pembelian atau penjualan antar perusahaan-perusahaan, yang dalampembayaran terkadang menggunakan Online Processing Credit Card, Money Transfer, atau Cash On Delivery jika alamat konsumen satu kota dengan penjual.Sebagian orang berpikir bahwa E-Commerce adalah shooping online, belanja,atau membeli sesuatu di internet. Transaksi online hanyalah sebagian kecil daritujuan E-Commerce. Dikarenakan memang sebagain besar fungsi dari pada ECommerce itu sendiri adalah sarana untuk berbisnis.

\section{F. Kebijakan Pajak E-Commerce}

Beberapa tahun belakangan ini, transaksi jual beli online atau lebih dikenal sebagai e-Commerce tumbuh subur dan berkembang pesat di Indonesia. Adanya peluang yang besar dan keuntungan yang menjanjikan, membuat banyak pengusaha lokal dan asing masuk ke industri perdagangan ini dengan memiliki online shop. Di sisi lain, seluruh penghasilan dari transaksi e-Commerce yang diterima juga dikenakan pajak E-Commerce. 


\section{G. Pengenaan Pajak Ecommerce}

Bagi pelaku usaha berskala kecil dan baru merintis, perlu diberikan sosialisasi terkait pengenaan pajak bisnis online di Surabaya. Pasalnya, aturanpajak e-commerce yang ditetapkan Direktur Jenderal dalam Surat Edaran DirekturJenderal Pajak Nomor SE-06/PJ/2015 tentang Pemotongan an/atau PemungutanPajak Penghasilan Atas Transaksi E-Commerce, masih terbilang baru diIndonesia. Oleh karena itu, pelaku online shop wajib memahami dan memenuhi kewajiban perpajakan yang dimuat dalam peraturan tersebut. Apabila dilihat dari aspek perpajakan, pengenaan pajak atas transaksi online ini akan membawa dampak positif dengan semakin terpercayanya toko online tersebut. Artinya, tidak mungkin ada aksi penipuan terhadap konsumen.Secara resmi memang belum ada aturan khusus pengenaan pajak atas situs-situs media sosial asing tersebut. Pada prinsipnya, pengenaan pajak tersebut sama dengan yang dikenakan atas transaksi E-Commerce yang harus dibayar pedagang dan pemilik online shop.

\section{H. Ketentuan Pajak Bagi Pelaku E-Commerce}

Pemerintah telah menerbitkan Peraturan Menteri Keuangan (PMK) Nomor 210/PMK.010/2018 tentang Perlakuan Perpajakan atas Transaksi Perdagangan melalui Sistem Elektronik. Pemerintah tidak menetapkan jenis atau tarif pajak baru bagi pelaku e-commerce.Pengaturan ini lebih menjelaskan tata cara dan prosedur pemajakan untuk memberikan kemudahan administrasi dan mendorong kepatuhan perpajakan para pelaku e-commerce demi menciptakan perlakuan yang setara dengan pelaku usaha konvensional.Pokok-pokok pengaturan dalam Nomor 210/PMK.010/2018 ini adalah sebagai berikut:

1. Bagi pedagang dan penyedia jasa yang berjualan melalui platform marketplace:

a. Memberitahukan Nomor Pokok Wajib Pajak kepada pihak penyedia platform marketplace

b. Apabila belum memiliki NPWP, pengusaha dapat memilih untuk (1) mendaftarkan diri untuk memperoleh NPWP, atau (2) memberitahukan Nomor Induk Kependudukan kepada penyedia platform marketplace

c. Melaksanakan kewajiban terkait $\mathrm{PPh}$ sesuai dengan ketentuan yang berlaku, seperti membayar pajak final dengan tarif $0,5 \%$ dari omzet dalam hal omzet tidak melebihi Rp4,8 miliar dalam setahun, serta

d. Dikukuhkan sebagai Pengusaha Kena Pajak dalam hal omzet melebihi Rp4,8 miliar dalam setahun, dan melaksanakan kewajiban terkait PPN sesuai ketentuan yang berlaku.

2. Kewajiban penyedia platform marketplace:

a. Memiliki NPWP, dan dikukuhkan sebagai PKP

b. Memungut, menyetor, dan melaporkan PPN dan PPh terkait penyediaan layanan platform marketplace kepada pedagang dan penyedia jasa

c. Memungut, menyetor, dan melaporkan PPN dan PPh terkait penjualan barang dagangan milik penyedia platform marketplace sendiri

d. Melaporkan rekapitulasi transaksi yang dilakukan oleh pedagang pengguna platform.

3. Bagi e-commerce di luar platform marketplace:

Pelaku usaha yang melaksanakan kegiatan perdagangan barang dan jasa melalui online retail, classified ads, daily deals, dan media sosial wajib mematuhi ketentuan terkait PPN, PPnBM, dan PPh sesuai ketentuan yang berlaku.

\section{Kewajiban Pengusaha Kena Pajak E-Commerce}

Sesuai dengan aturan pajak e-Commerce 2019 tersebut, PKP Pedagangatau PKP Penyedia Jasa yang melakukan penyerahan Barang Kena Pajak (BKP)dan/ atau Jasa Kena Pajak (JKP) secara 
elektronik (e-Commerce) melaluiPenyedia Platform Marketplace diwajibkan memungut, menyetorkan, danmelaporkan:

1. Pajak Pertambahan Nilai (PPN) yang Terutang. Tarif pengenaan pajaknyasebesar $10 \%$ dari nilai transaksi penyerahan Barang Kena Pajak dan/ atauJasa Kena Pajak.

2. Pajak Pertambahan Nilai dan Pajak Penjualan atas Barang Mewah.Ketentuan pengenaan pajak jenis ini mengikuti tarif dan tata carapenyetoran dan pelaporan sesuai dengan ketentuan peraturan perundangundangan.

Dalam peraturan pajak e-Commerce 2019 ini juga menegaskan PKPPedagang dan PKP Penyedia Jasa wajib melaporkan kewajiban pajaknyadalam SPT Masa PPN setiap masa pajak atas penyerahan BKP dan/ atau JKPyang melalui penyedia platform marketplace.

\section{J. Kerangka Konsep Penelitian}

Adapun kerangka konsep dalam penelitian ini dapat digambarkan sebagai berikut:

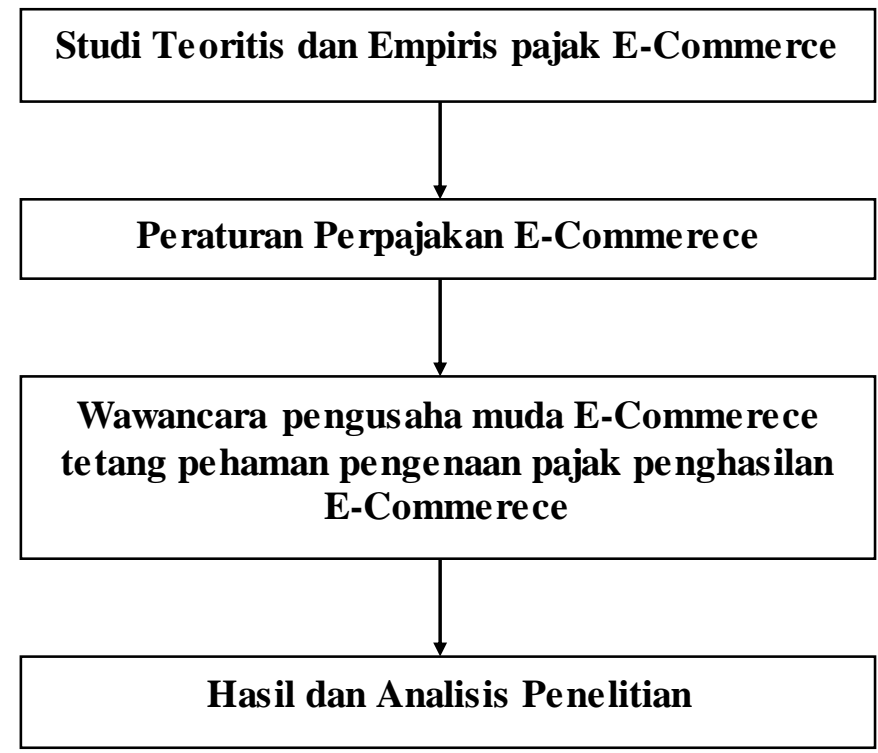

Gambar 4. Kerangka Konsep Penelitian

Penelitian menggunakan konsep analisi deskriftif dengan membandikan hasil studi teoritis, studi empiris, dan hasil wawancara pelaku bisnis E-Commerece yang berusia di antara 21-30 tahun. Sebagai dasar penelitian.

\section{METODE}

Pendekatan penelitian ini adalah dengan pendekatan kualitatif yang dilakukandengan menguraikan data-data yang diperoleh secara diskriptif denganmenggunakan pendekatan penelitian fenomenologi. Penelitian kualitatif merupakan penelitian yang bermaksud untuk memahamifenomena mengenai hal yang dialami oleh subjek penelitian dengan cara deskripsidalam bentuk kata-kata dan bahasa, pada suatu konteks khusus yang alamiahdengan memanfaatkan berbagai metode ilmiah. Penelitian ini menggunakan polanon-liner(cyclical) yang memungkinkan peneliti untuk mengulang langkahlangkah penelitian hingga tercapai hasil optimal (logic in practice). 
Jenis dan sumber data untuk penelitian dapat diperoleh dari berbagai macamhal. Berdasarkan cara memperoleh data penelitian, sumber data untuk penelitianyang berasal dari dua sumber yaitu sumber data primer dan data sekunder.Data primer adalah data yang diperoleh langsung dari sumbernya, contohnyadata yang diperoleh dari responden melalui kuisioner, kelompok fokus, panel ataujuga data hasil wawancara peneliti dengan narasumber.Data sekunder adalah sumber data yang tidak langsung memberikan datakepada peneliti atau data yang diperoleh peneliti dari sumber yang sudah ada,misalnya catatan, dokumentasi perusahaan, data yang diperoleh dari majalah danlain sebagainya. Sumber data dalam penelitian ini diperoleh melalui hasilwawancara peneliti dengan narasumber sedangkan sumber data sekunderdiperoleh dari UU PPh E-Commerce.

\section{HASIL DAN PEMBAHASAN}

Berdasarkan Undang-Undang No. 36 tahun 2008 Tentang Pajak Penghasilan pasal 2 ayat (1) yang menjadi subjek ajak penghasilam adalah :

a. Orang pribadi

b. Warisan yang belum terbagi sebagai satu kesatuanmenggantikan yang berhak;

c. Badan; dan

d. Bentuk usaha tetap

Maka pengusaha perorangan yang melakukan bisnis E-Commerce dapat digolongkn sebagai subjek pajak orang pribadi. Subjek pajak orang pribadi E-Commece yang merupakan pengusaha yang bersifat individu dalam menjalankan usahanya. Dapat dicontohkan sebagai pemilik toko online dengan tanpa adanya tempat usaha nyata. Sehinggabentuk transaksi orang pribadiperdagangan online menggunakanmedia elektronik seperti telepon,komputer pribadi, online shop, Automatic Teller Machine (ATM), smart card atau smart phone, melaluisaluran telekomunikasi seperti jaringantelepon publik tradisional, jaringankomputer, jaringan komputer yangbergerak, dan sejenisnya

Dan berdasarkan pada pasal 4 ayat (1) undang-undang No 36 Tahun 2008 Tentang pajakpenghasilan, yang menjadi objek pajak adalahpenghasilan, yaitu setiap tambahankemampuan ekonomis yang diterima atauyang diperoleh wajib pajak, yang dapatdipakai untuk konsumsi atau untuk menambahkekayaan wajib pajak yang bersangkutan,dengan nama dan dalam bentuk apapun.Karena setiap transaksi jual-beli pastimemperoleh keuntungan dan keuntungan yangdidapatkan oleh pengusaha itulah yangmerupakan suatu penghasilan. Sehingga syaratsubjektif orang pribadi dan syarat objektif telah terpenuhi.

Menurut Tahar dan Septiani (2021) menyatakan bahwa seharusnya pengusaha online dikenakan pajak penghasilan atas objek pajak penghasilan dari perdagangan online yang telah dilakukan. Pemungutan atas pajak penghasilan bukan merupakan peraturan baru melainkan penegasan peraturan yang telah ada namun pemungutannya belum terlaksanakan secara maksimal dikarenakan sulitnya akses untuk mengetahui besarnya penghasilanpengusaha online secara keseluruhan.

Pada E-Commerce tidak ada perbedaan dengan transaksiperdagangan secara konvensional, hanya saja karena transaksi yang digunakan melalui mediaelektronik, maka menjadi hal yang penting dalam penegasan aspek perpajakannya (Suprihatin dan Afriyanti, 2021). Surat Edaran Direktorat Jendral Pajak Nomor SE-62/PJ/2013 tentang penegasanKetentuan Perpajakan atas Transaksi E-Commerce telah dijelaskanbahwa perlu adanya pengoptimalan dalam potensi penerimaan pajak dari transaksiECommerce. Secara garis besar, karena model transaksi yang cukup sederhana sertakegiatan yang dapat dilakukan dimana saja, maka transaksi ini menjadi daya tarik tersendiribagi para pelakunya. Dalam penanganan yang telah dilakukan oleh pihak Direktorat JendralPajak terdapat empat model transaksi ECommerce beserta aspek perpajakannya.Untuk PPh dapat dihitung berdasarkan peredaran usaha, penghasilan lain maupunpenghasilan bruto dikalikan tarif PP No 23 tahun 2018 yaitu 0,5\%. Dilihat 
dari segipemungutan,sebenarnya pihak pajak tidak memungut pajak melainkan pihak pajak memberikepercayaan kepada wajib pajak untuk menghitung pajak terutang yaitu denganmenggunakan metode self assessment system. Self assessment system adalah suatu sistem perhitungan pajak yang memberi wewenang kepada wajib pajak untuk menentukan sendiribesarnya pajak yang terhutang. Kemudian untuk perhitungan pemungutan nya sendiri, samahalnya dengan perhitungan pemungutan undang-undang perpajakan yang berlaku.hanya sajauntuk penghasilan yang didapat itu dikenakan 0,5\% dari omzet, jumlah omzet dibawahRp.4.800.000.000 terhitung semua pajak terutang kecuali.

Pengusaha online di era sekang ini lebih didominasi oleh para generasi muda yang berusia 21-30 Tahun. Hal ini disebabkan dari semakin susahnya dalam mecari pekerjaan dan timbulnya jiwa berwirausaha generasi muda Indonesia. Dengan memanfaatkan era digital yang memberikan penawaran kemudahan dalam berwirausaha. Sekarang ini berwirausaha sudah tidak ada batasan baik dalam ruang dan waktu. Dengan digital berwirausaha dapat dilakukan kapan saja dan dimana saja. Bias dilakukan lintas kota, provinsi, bahkan lintas Negara. Kemudahan ini membuka peluang para generasi muda untuk memperoleh keuntungan yang mugkin tidak terbatas. Selain sebagai pengusaha generasi muda juga aktif dalam membelanjakan penghasilannya di dunia E-Commerce. Fakta ini dapat dilihat dari grafik data dibawah :

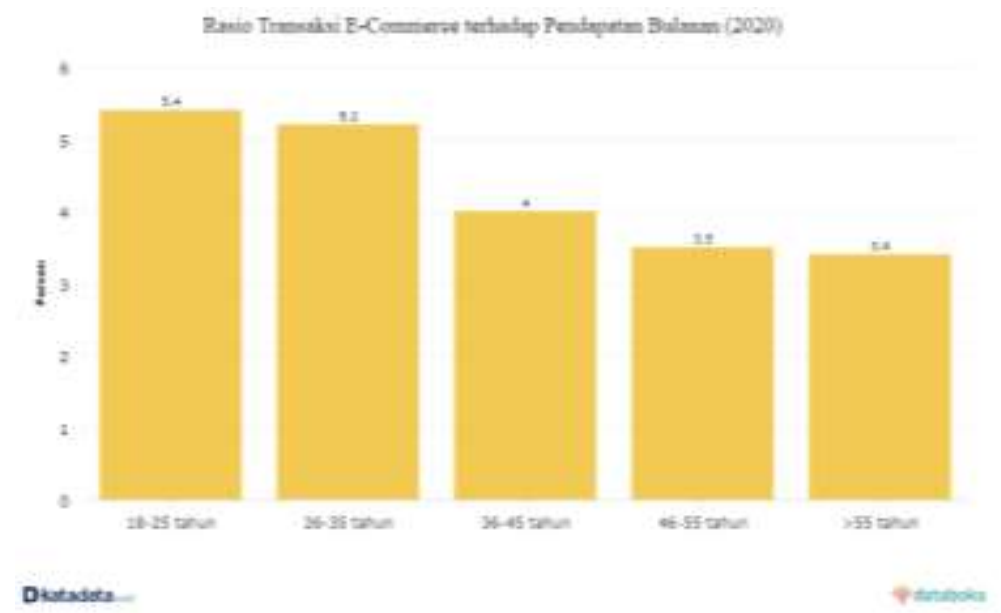

Gambar 5. Rasio Transaksi E-Commerce Terhadap Pendapatan Bulanan (2020) Sumber : https://databoks.katadata.co.id

Dilihat dari grafik data diatas bahwa masyarakat berusia 18-25 tahun rata-rata dapat melakukan transaksi E-Commerce sebesar 5,4\% dari jumlah pendapatan bulanannya. Masyarakat berusai 26-35 tahun rata-rata dapat melakukan transaksi E-Commerce sebesar 5,2\% dari julah pendapatan bulannnya. Masyarakat berusai 36-45 tahun rata-rata dapat melakukan tansaksi E-Commerce sebesar 4\% dari jumlah pendapatan bulanannya. Masyarakat berusai 46-55 tahun rata-rata dapat melakukan tansaksi ECommerce sebesar 3,5\% dari jumlah pendapatan bulanannya. Sedangkan masyarakat berusia diatas 55 tahun rata-rata dapat melakukan transaksi E-Commerce sebesar 3,4\% dari jumlah pendapatan bulanannya. Menurut Lidwina (2021) menyatakan bahwa generasi Z dan milenial banyak yang menghabiskan pendapatan bulanannya untuk berbelanja di E-Commerce.

Transaksi-transaksi E-Commerce yang dilakukan oleh generasi mudah ini dapat mengidentifikasi adanya peluang dalam pengenaan pajak, baik dari pajak penghasilan maupun dari pajak pertambahan nilai atas barang yng dijual beli secara online. Akan tetapi peluang ini masih rentan untuk dideteksi, mengingat perdangangan dilakukan secara online. Perdanganagn online dilakukan tanpa bertemunya penjual dan pembeli sehingga tidka terlihat siapa penjual dan siapa pembelinya, dan dilakukan diwaktu yang tidak terbatas jadi kapan saja bias dilakukan. Dan bisa menjangkau kemana saja. Hal ini lah yang 
mungkin susah untuk diidentifikasi pemerintah. Sehingga pemerintah masih kurang maksimal dalam pajak E-Commerce.

Berdasarkan wawancara yag telah dilakukan secara mendalam terhadap narasumber maka dapat disimpulkan sebagian besar generasi muda yang memiliki usaha dibidang E-Commerce masih belum mampu memahami konsep pengenaan pajak atas penghasilan yang didapatnya.Ketidakpahaman generasi muda pengusaha online yang merupakan wajib pajak penghasilan dapat menimbulkan berbagai macam permasalahan perpajakan. Misalkan belum sadarnya mereka akan kewajiban mereka sebagai wajib pajak orang pribadi dalam melaporkan penghasilan atau pendapatan mereka pada Negara dan belum mengetahui tujuan dari pentingnya membayar pajak bagi Negara. Dalam hal ini juga menunjukkan bahwa sosialisasi peraturan perpajakan terutama tentang pajak penghasilan E-Commerce masih belum berjalan secara maksimal yang mengakibatkan pemahaman wajib pajak orang pribadi atas penghasilan E-Commerce masih rendah.

Generasi muda pelaku pengusaha E-Commerce masih kurang dalam memahami pengenaan pajak yang sesuai dengan peraturan perundang-undangan perpajakan yang telah ditetapkan oleh pemerintah. Sehingga generasi muda masih belum mampu dalam myusun atau melaporkan penghasilan mereka pada pemerintah. Pemerintah sudah memudahkan wajib pajak untuk dapat melakukan pelaporan mandiri secara online dengan menanfaatkan metode Self assessment system,metode ini dapat digunakan dengan mudah oleh generas muda dalam menghitung dan melaporkan besar pajak yang akan dibayar. Metode Self assessment system dilakukan secara online untuk memudahkan generasi muda yang merupakan wajib pajak. Akan tetapi seluruh kemudahaan ini masih belum dimanfaatkan oleh generasi muda dalam membayar pajak akibat dari masi kurangnya pengetahuan danpemahaman mereka tentang hal ini. Sehingga kesadaran generasi muda dalam membayar pajak masih rendah.

Para generasi mudah masih berfikir bahwa membayar pajak merupakan suatu beban yang harus dilakukan oleh mereka. Hal ini disebabkan kurangnya pengetahuan mereka tentang pentingnya pajak bagi masyarakat dan pemerintah. Manfaat pajak yang telah dibayar pada Negara sebenarnya dapat mereka nikmat juga, seperti pembangunan infrastruktur, mendirikan fasilitas kesehatan, mendirikan fasilitas pendidikan, dan menstabilkan perekonomian Negara. Pada intinya membayar pajak dapat mensejahterakan dan memakmurkan rakyat Indonesia yang termasuk diri mereka sendiri para generasi muda. Manfaat-manfaat ini masih belum disadari oleh generasi muda, begitu pentingnya membayar pajak pada Negara untuk dinikmati manfaatnya secara bersama-sama.

Dengan hal ini seharusnya pemerintah lebih mensosialisasikan peraturan perpajakan terutama pajak E-Commerce yang sedang digemari oleh generasi muda dalam mendapatkan penghasilannya. Sehingga pemerintah tidak kehilangan peluang dalam mendapatkan pendapatan Negara atas pajak. Generasi muda merupakan generasi yang diharapkan untuk mampu mempertahankan dan mengembangkan suatu Negara terutama dalam bidang perekonomian. Pemerintah seharusnya sudah mulai merangkul generasi muda untuk ikut serta dalam membangun dan memgembangakan perekonomian Negara dengan sadar akan pentingnya membayar pajak.

\section{KESIMPULAN}

Berdasarkan hasil dari penelitian yang telah dilakukan maka dapat disimpulkan bahwa masih rendahnya tingkat pemahaman pajak penghasilan atas pendapatan dari melakukan kegiatan bisnis ECommerce yang dilakukan oleh subjek pajak yang dalam hal ini adalah pengusaha muda berusia 21-30 tahun yang memiliki toko online dan atau yang memiliki usaha dalam E-Commerece, sehingga tingkat kesadaran dalam melaporan pajak penghasilannya juga masih rendah.Sosialisasi peraturan perpajakan atas E-Commerece juga masih rendah yang mengakibatkan para pelaku E-Commerce tidak memahami 
peraturan perpajakan E-Commerece sehingga berpotensi menghilangkan pendapatan Negara atas pajak penghasilan tersebut.

\section{REFERENSI}

[1] Aprilia, Anita, Astuti \& Nuzula, 2014. Penanganan dan Pengawasan Perpajakan dalam Intensifikasi di Bidang e-Commerce (Studi pada KPP Pratama Malang Selatan). Jurnal Mahasiswa Perpajakan Vo.2, No.1

[2] Bohari, Pengantar Hukum Pajak, Rajawali Pers, Jakarta, 2012

[3] Coupey, E., 2001. Marketing and the internet. Prentice Hall PTR.

[4] Eviera,Maharani Utomo. 2013. Transaksi E-Commerce Sebagai Potensi Penerimaan Pajak di Indonesia. Jurnal Akuntansi Unesa, Vol.2 No.1,01-20

[5] Internet, WS (2018). www.statista.com, from https://www.statista.com/statistics/249562/number-ofworldwide-internet-users-by-region/

[6] Jabbar, HA and J. Pope, 2008. The effects of the self-assessment system on the tax compliance costs of small and medium enterprises in Malaysia. Journals in Business \& Management, 3(4): 289-307.

[7] Lidwin, Andrea,2021, Rasio Transaksi E-Commerce Terhadap Pendapatan Bulanan (2020).https://databoks.katadata.co.id/datapublish/2021/06/09/gaji-generasi-z-dan-milenial-banyakibelanjakan-di-e-commerce

[8] Loudon, K. C., \& Loudon, J. P. 2004. Sistem Informasi Manajemen (Managemen Information Systems, Managing the Digital Firm) Terjemahan. Yogyakarta: Andi.

[9] Luciana, S.A. 2013. Penerapan E-commerce Sebagai Upaya Meningkatkan Persaingan Bisnis Perusahaan. STIE Perbanas Surabaya. Surabaya

[10] Redae, RB and S. Sekhon, 2016. Taxpayers "e knowledge and tax compliance behavior in Ethiopia: A study of Tigray State. International Journal of Management and Commerce Innovations, 3(2): 10901102.

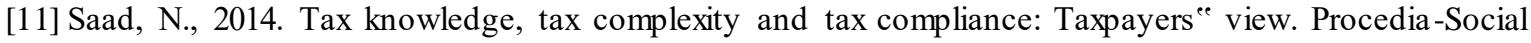
and Behavioral Sciences, 109: 1069-1075. Available at: https://doi.org/10.1016/j.sbspro.2013.12.590.

[12] Sikka, P. (2008). Globalization and its discontents: Accounting firms buy limited liability partnership legislation in Jersey. Accounting, Auditing and Accountability Journal, 21(3), 398-426. https://doi.org/10.1108/09513570810863987

[13] Sumedi, N.A., 2010. Acceptance of e-payment for tax purposes in Malaysia. Doctoral Dissertation, University of Malaya, Malaysia.

[14] Surat Edaran Pajak Nomor SE-62/PJ/2013 tentang Penegasan Ketentuan Perpajakan atas Transaksi ECommerce.

[15] Tahar, A., \& Septiani, D.D. (2021). Pengenaan Pajak Penghasilan terhadap Pengusaha dalam Transaksi Perdagangan Online (Ecommerce) Studi Pengusaha Online di Yogyakarta. EJurnal Akuntansi, 31(6), $1390-1400$

[16] Undang-Undang Dasar Negera Republik Indonesia Tahun 1945

[17] Undang-Undang Nomor 11 Tahun 2008 Tentang ITE (Lembaran Negara Repulik Indonesia Tahun 2008 Nomor 59, Tambahan Lembaran Negara Republik Indonesia Nomor 4843) 
[18] Undang-Undang Nomor 36 Tahun 2008 tentang Perubahan Keempat atas Undang-Undang Nomor 7 Tahun 1983 tentang Pajak Penghasilan

[19] OECD (2017). Taxing Wages - France Retrieved from https://www.oecd.org/france/taxing-wagesfrance.pdf

[20] Peraturan Menteri Keuangan (PMK) Nomor 210/PMK.010/2018 tentang Perlakuan Perpajakan atas Transaksi Perdagangan melalui Sistem Elektronik

[21] Peraturan Pemerintah Nomor 46 Tahun 2013 Tentang pajak Penghasilan Final (Lembaran Negara Republik Indonesia Tahun 2013 Nomor 106, Tambahan Lembaran Negara Nomor 5424)

[22] Peraturan Direktur Jendral Pajak Nomor PER-32/PJ/2010 Tentang Pelaksanaan Pengenaan Pajak Penghasilan Pasal 25 Bagi Wajib Pajak Orang Pribadi Pengusaha Tertentu)

[23] Pham, L., L.N. Pham and D.T.T. Nguyen, 2011. Determinants of e-commerce adoption in Vietnamese small and medium sized enterpris es. International Journal of Entrepreneurship, 15(1): 45-72. 